\title{
'Tri-Nationality' as Major Challenge to Cluster Development - Experiences from the BioValley Initiative
}

\author{
Bernhard Fuhrer*
}

\begin{abstract}
The paper analyzes the organizational transformation of the biotechnology cluster initiative in central Europe. In the tri-national context of the BioValley (France, Germany, Switzerland), cross-border collaboration is the key variable under scrutiny. Two distinct development stages are identified: The initial 'tri-national' phase characterized by a centralized governance structure and the second, 'regional' stage characterized by decentralized governance structures. In summary, neither organizational setups have managed to tackle the tri-national heterogeneity in a way that would fully unleash the potential of the region. Individual and territorial egoisms were at the heart of this shortcoming. The article therefore concludes by suggesting that whatever executive form (centralized or decentralized) the organization takes in the future, it must implement projects that are selected by an economically and territorially independent jury.
\end{abstract}

Keywords: Biotechnology · BioValley $\cdot$ Cluster $\cdot$ Regional development policy

\section{The Cross-Border Network Challenge}

When the tri-national BioValley Project was launched in 1996, its founders were clearly inspired by the famous 'Silicon Valley' phenomenon. Their idea was straightforward and - at least for Swiss standards - atypically ambitious: The BioValley should become for the emerging biotechnology sector what the Silicon Valley had become for the IT industry. In many ways, this goal was even more ambitious than that of its famous role model: Not only should the future BioValley regionally 'network' the public and private players but it should do so across three national borders. The initiators argued that only the constituent German, French, and Swiss parts could muster the critical mass necessary for a sustainable cluster development. Its regional focus was thus 'complicated'; the project had to measure up to a twofold challenge: 1) the regional, Californiastyle networking ambition 2) the cross-border collaboration necessity.

This contribution will only investigate the second BioValley characteristic, i.e. its insis-

${ }^{*}$ Correspondence: Dr. B. Fuhrer

Economic Geography

University of Bern

Hallerstrasse 12

$\mathrm{CH}-3012$ Bern

Tel.: +41316318865

Fax: +41316318511

E-Mail: fuhrer@giub.unibe.ch tence on cross-border collaboration. Focusing on the organizational change within the BioValley, it will do so by redrafting the development of the initiative, suggesting that there has been a two-stage development. The first stage can be characterized as "tri-national and centralized'.

\section{First Stage: 'Tri-National and Centralized'}

The founding event of the BioValley on October 8th 1996 was strongly marked by the new geographical awareness. Beat Löffler, later Secretary General of the BioValley, had lobbied intensively to assemble a poster depicting the Upper Rhine valley mapping all the biotech-related players in this 'artificial' tri-national region. The map was special in that it overlooked national borders. The effect of the visual artistry was, as Löffler recalls it, "like a coup d'etat'. The participants of the meeting were thrilled at the prospects of potential collaborations, but they had little notion of how to organize such a network efficiently. Fritz Bühler ended the initial debate by swiftly proclaiming the participants of the meeting to be the constituent members of the tri-national BioValley. The newly forged BioValley members agreed that the aim was to create horizontal networks with as little overhead as possible and thus voted to have a Secretary General that would centrally coordinate the activities. Following this organizational installment the proj- ect was therefore not only 'cross-border' but also 'centralized'. Both concepts were advertised as 'unique selling propositions' and rightly became the cornerstones of the BioValley project. Firstly, the tri-nationality guaranteed half of BioValley's ultimate funding through the co-financed European Interreg II \& III grants - the co-financers being the involved three regions in France, Germany and Switzerland, respectively. Secondly, the 'centralized' approach was further strengthened by the first BioValley Steering Committee that included a delegation from each country, which itself each included members from university, technology transfer, economic development agency, and industry. Within this vast governing body it soon became clear that the marriage of the tri-national and centralized approach proved to be less easy to implement than anticipated. The founders had underestimated the cultural differences among the partners and the political involvement engendered through the co-financing system.

\section{Cultural Differences and Political Involvement}

In a memorable speech held at the 1999 BioValley annual conference, Philippe Poindron, then member of the Steering Committee, told the audience of the 'tough realities' of such tri-national day-to-day work. He smilingly reported that 'the Swiss are mad that the French are always late, the French are upset because the Germans refuse to speak French and 
the Germans complain that the Swiss only think about money'. In his statement Poindron humorously wrapped up a more general 'malaise' among the BioValley members. Its tenor: the tediousness of cross-cultural cooperation! More than once sessions of the Steering Committee ended in dispute and shifting alliances and counter alliances were forged among its members. Often the disputes surrounded questions of workload and part of the BioValley 'fame', but the questions of financial involvement and the share of the benefits were the recurring themes and undercurrent concerns. Retrospectively, part of the problem was the tri-national financial involvement mentioned before. Doubting the efficiency of the Steering Committee, the regional co-financers began to press for more influence. At that moment, private players criticized that the initiative was being engulfed by politics. The co-financers on their side argued that many private players were behaving egoistically and that they were exclusively promoting their own agendas. Power battles ensued, heads rolled and the winning political faction rang the bell for a new era of BioValley development. Inevitably, the stronger involvement of territorially bound reasoning threatened the original 'tri-national' and 'central' approach. The BioValley therefore entered a second stage of development which can be characterized as 'regional and decentralized'.

\section{Second Stage: 'Regional and Decentralized'}

The most ostensible change in the organization of the BioValley was the strengthening of the three national BioValley Associations. While a central organization was founded to act as a common roof, it had nowhere near the executive powers of the Steering Committee in the past. Thus the new organizational setup was strongly decentralized. The overall picture was one of a 'retreat to the national spheres', a development that many participants considered to be 'pragmatic' and 'in line' with the political realities of the financing model. It is largely uncontested that the economic development agencies have been instrumental in this overall decentralization of the project.

The lack of a powerful central structure has not, however, disrupted key pillars of BioValley activity. The external marketing via the webpage and the BioValley Journal resumed with the arrival of the Interreg III funds and the respective national BioValley associations continued their local networking activities, most notably with their 'Stammtische' i.e. informal gatherings of BioValley members. On this level, networking persisted and even the tri-national Stammtische were still held regularly. On the other hand, a recent study carried out in the French part of the BioValley shows that the French public sector researchers never engage in collaboration with Swiss or German re- search labs or indeed with Swiss or German companies. Collaboration is uniquely reserved to the French side. This points to the fact that despite the existence of the 'Stammtische', cross-border collaboration is still underdeveloped and that perhaps the networking activities of the 'regional and decentralized' phase have done little to strengthen such ties - to be fair, it has to be added that even the tri-national phase has evidently not broken much ground in this respect. Be it as it were, the impression of relatively underdeveloped cross-border relations correlates with the fact that the economic development agencies have difficulties overcoming their territorial stance. Bound by their mandate, they simply cannot commit for ventures beyond their administrative space and overall still see little incentive to engage in large-scale cross-border cooperation. If one still assumes that the cross-border collaboration indeed catalyzes the cluster, then one should allow the question whether the BioValley should not again 'tri-nationalize', thus turning back to its initial ambition of cross-border activity. One should ask, in other words, whether the regional egoisms that have characterized the secondstage development should not be superseded by a third-stage development, which takes the financing realities into account, but does so without scarifying tri-national potential. The task is, therefore, to outline a roadmap for a future third-stage BioValley development.

\section{Future Third Stage: Tri-Nationalization and Charter of Conduct or Disintegra- tion}

The key paradox of a prospective thirdstage BioValley lies in the inherent contradiction of the co-financers and the original ideal of tri-national, cross-border collaboration. In fact, the basic collaboration- and redistribution question has not changed since the initial days: Who will receive what benefit from the collectively invested work and money? In so far as the economic development agencies will now be the key players in the future, they will either need to agree on a 'charter of conduct', i.e. a consensus paper defining the rules of fair competition between the engaged parties, or to abandon the tri-national perspective altogether. Such a 'charter of conduct' is as primordial as a 'common ground of trust' that makes it possible for the agencies to engage in projects that go beyond their territorial realm. In practice, such an agreement-based collaboration needs to be translated in an organizational form on two distinct levels: the management level and the project approval level:

On the management level a "charter-based collaboration' can translate into a various organizational forms. Thus it is conceivable to revert to a centralized executive-style management, which is only indirectly controlled by the co-financers. Or, such collaboration could also translate into a more decentralized form, i.e. by strengthening the current structures of the national associations. The advantage of the former setup is its partial 'decoupling' of the immediate national context; the advantage of the latter is its proximity to the 'field'. The history of the BioValley initiative has shown that both variants have existed in the past and both approaches have their advantages and their drawbacks. However, regardless which managerial form the future BioValley takes, the even more important consequence of a 'charter of conduct' concerns the project approval level.

On the project approval level the 'charter of conduct' would dictate that funds do not have to be allocated proportionally to the participants' contributions. Instead, funds should be allocated to priority projects. In other words, funds would be allocated on the basis of priority and NOT parity as has been the case in the 'regional'-stage of the BioValley development. Secondly, the charter should insist that projects be selected by an independent jury without direct business or territorial interests. In other words, project selection should be based on quality and NOT proximity of the players as it has been the case in the 'tri-national' stage of development. It is the author's belief that both targets can only be achieved by a regionally and economically independent project jury. It follows that such a jury would need to be institutionally integrated into the new organizational structure of the BioValley. Admittedly these two prescriptions - project selection based on priority NOT parity and project selection based on quality NOT proximity will be hard to accept in the current mindset. However, the uncertain future of the initiative leaves little room for timid reform. It is a time of important decisions.

\section{Important Decisions to Overcome Past Egoisms}

So far the development of the BioValley has shown a shift from a 'tri-national' and 'centralized' start-up phase to a more pragmatic 'regional' and 'decentralized' phase. The difficulties of cross-border collaboration have become more than obvious and have revealed that what was thought to be a 'unique selling proposition' has turned out to be a major organizational handicap. Essentially, the BioValley has fallen victim to private, economic egoisms in its first development stage and it has fallen victim to political, territorial egoisms in its second development stage. Today, without much room for maneuver, the BioValley has to learn from its past and it has to be bold enough to implement institutional changes that might not coincide with the current habits. As a life-science cluster, the BioValley is about to swallow a bitter, yet much needed medicine that will hopefully lead the way to a successful third stage development.

Received: October 13, 2004 